\title{
WOOD DRYERS: A SUSTAINABLE ALTERNATIVE FOR INCREASED CHARCOAL PRODUCTION
}

\author{
Clarissa Gusmão Figueiró ${ }^{1}$, Angélica de Cássia Oliveira Carneiro ${ }^{1}$, Lucas de Freitas Fialho ${ }^{1}$, Mateus Alves de Magalhães ${ }^{1}$, Gabriel Browne \\ de Deus Ribeiro ${ }^{1}$, Fernanda Barbosa Ferreira
}

${ }^{1}$ Federal University of Viçosa, Department of Forestry Engineering, Viçosa, Minas Gerais, Brazil-clarissagfigueiro@gmail.com, cassiacarneiro1@gmail.com, 1.freitasfialho@gmail.com, mateusmagalhaes91@gmail.com, gabrielbrowne@gmail.com, ferreirabf@outlook.com

Received for publication: 09/05/2018 - Accepted for publication: 20/08/2019

\begin{abstract}
Resumo
Secadores de madeira: uma alternativa sustentável para o aumento da produção do carvão vegetal. O objetivo do presente estudo foi avaliar a viabilidade técnica e econômica de um secador de madeira na produção de carvão vegetal. A secagem foi realizada durante 72 horas, utilizando madeira de Eucalyptus sp. em duas classes de diâmetro, com temperatura média de admissão de gases combustos no secador entre 100 e $150^{\circ} \mathrm{C}$. Foi determinada a massa de água retirada pela secagem e estimada a quantidade de madeira que seria consumida durante a carbonização para remoção da mesma quantidade de água, sendo essa madeira convertida em massa de carvão. Na análise econômica foram determinados os indicadores valor presente líquido, taxa interna de retorno e o payback descontado. O secador apresentou viabilidade técnica, reduzindo em $8 \%$ a umidade da madeira e, consequentemente, aumentando em 3,3\% a produtividade de carvão vegetal, e viabilidade econômica, com bons indicadores financeiros para as condições atuais de mercado, incluindo um payback descontado de 6 anos. Desta forma, a utilização de um secador de madeira apresentou-se como uma forma eficiente de aproveitamento de um passivo ambiental da carbonização, o que contribui para o aumento da sustentabilidade na produção de carvão vegetal.

Palavras-chave: Umidade, Eucalyptus sp., Carbonização
\end{abstract}

\begin{abstract}
The aim of the study was to evaluate the technical and economic viability of a wood dryer in the charcoal production. Drying was carried out for 72 hours using wood from Eucalyptus sp. in two classes of diameter. The average admission temperature of combustion gases in the dryer was $100-150^{\circ} \mathrm{C}$. It was determined the mass of water withdrawn by drying and estimated the amount of wood that would be consumed during the pyrolysis to remove the same amount of water, being this wood converted into charcoal mass. In the economic analysis were determined the indicators net present value, internal rate of return and discounted payback. The dryer presented technical feasibility, reducing wood moisture by $8 \%$ and, consequently, increasing the charcoal productivity by $3.3 \%$, and economic viability, with good financial indicators for current market conditions, including a discounted payback of 6 years. In this way, the use of a wood dryer was presented as an efficient way to take advantage of an environmental liability of pyrolysis, which contributes to the increase of sustainability in the charcoal production.
\end{abstract}

Keywords: Moisture, Eucalyptus sp., Carbonization

\section{INTRODUCTION}

Concerns about fossil fuel dependence and climate change have made the use of renewable energy sources a strategic point for the sustainable development of nations (VERMA et al., 2017). According to the IEA / ARENA Global Renewable Energy Policies and Measures Database, more than 60 countries have national goals or policies to support the use of renewable energy sources (IEA, 2017). Brazil is a privileged country in this regard, being responsible for one of the world's most renewable energy matrices, representing $43.5 \%$ of these energy sources. In addition, it has great potential for expanding the use of this type of resource (WELFLE, 2017).

The use of residues from agroforestry industries, in this sense, contributes to the expansion of sustainability and diversification of the national energy matrix. By converting potential environmental liabilities into economically viable by-products, industrial sectors have the opportunity to develop a circular production chain based on the incorporation of residues as integral components of the production system (KORHONEN et al., 2018).

In the Brazilian forest industry, the charcoal sector is an example of a chain that presents some productive practices that can be improved, such as the proper disposal of gases produced during carbonization. Charcoal is obtained by slow pyrolysis or carbonization of wood, which has as its main product a carbon-rich solid and a

FLORESTA, Curitiba, PR, v. 50, n. 1, p. 943 - 952, jan/mar 2020

Figueiró, C. G. et.al.

ISSN eletrônico 1982-4688

DOI: $10.5380 /$ rf.v50 i1.59355 
volatile fraction consisting of gases and condensable organic vapors (PEREIRA et al., 2012). Such gases are classified as inert $\left(\mathrm{CO}_{2}\right.$ and $\left.\mathrm{N}_{2}\right)$ and combustible $\left(\mathrm{CO}, \mathrm{CH}_{4}\right.$ and $\left.\mathrm{C}_{\mathrm{n}} \mathrm{H}_{\mathrm{n}}\right)$. However, mainly due to the presence of environmentally harmful gases, such as $\mathrm{CH}_{4}$ (methane), a gas that has a high potential for global warming, and $\mathrm{CO}$ (carbon monoxide), whose inhalation is associated with respiratory problems and carcinoma (PENNISE et al., 2001), alternatives should be sought for the destination of these gases.

During carbonization, in most companies, gases are released into the atmosphere without minimizing their harmful and polluting effect. Thus, mitigation procedures for such liabilities are required due to increasing pressure from national and international environmental agencies. Combustion is an attractive alternative that assists in the environmentally correct disposal of gases, as it can reduce more than $80 \%$ of the methane emitted in the process, depending on the type of combustion chamber (PEREIRA et al., 2017). Another benefit of combustion is the generation of thermal energy, which can be directed in wood dryers.

The use of wood dryers in charcoal production is still incipient, but it has great potential. By drying the wood, the carbonization cycle is reduced, as well as increasing the gravimetric yield in charcoal, since part of the energy available in the system will be directed to the drying surface of the wood. The implementation of dryers in charcoal producing units means a reduction of an environmental liability, ensuring an improvement in the efficiency and sustainability of the production process. Thus, the objective was to evaluate the drying efficiency and economic viability of a wood dryer to be used in industrial charcoal production.

\section{MATERIAL AND METHODS}

The present study was developed in a charcoal production unit located in the municipality of Martinho Campos - MG. The climate of the region is type Cwa, according to the Köppen classification, characterized by humid summers and dry winters, with an average annual temperature between 19.8 and $25.3^{\circ} \mathrm{C}$, and an annual average precipitation of 1,400 mm (GOMIDE et al., 2009 ). Approximately $280 \mathrm{~m}^{3}$ of Eucalyptus sp. wood was used in the study, $140 \mathrm{~m}^{3}$ in each drying process, from plantations aged 7 to 8 years old. The approximate length of the logs was 3.0 meters.

\section{Artificial wood drying}

The dryer was constructed with $2.00 \mathrm{~mm}$ galvanized plate, structured in square profile, $40 \mathrm{~mm}$ thick walls with thermal insulation made with aluminized ceramic fiber blanket, with a density of $160 \mathrm{~kg} / \mathrm{m}^{3}$ and a thickness of $38.10 \mathrm{~mm}$.

Inside the dryer were installed axial fans and metal curtains to facilitate the circulation of the combustion gases, thus homogenizing and accelerating the drying process. After circulation inside the dryer, the combustion gases were released into the environment in openings between the doors and the metal dryer floor.

To obtain the temperature profile of the dryer, 28 monitoring points (thermocouples) were distributed along the dryer, two located in each of the doors (totaling 16), two in each side, four in the ceiling, three in the piping for hot gases and one in the exhaust fan. Figures 1 and 2 show the floor plan and the schematic diagram of the metal dryer.

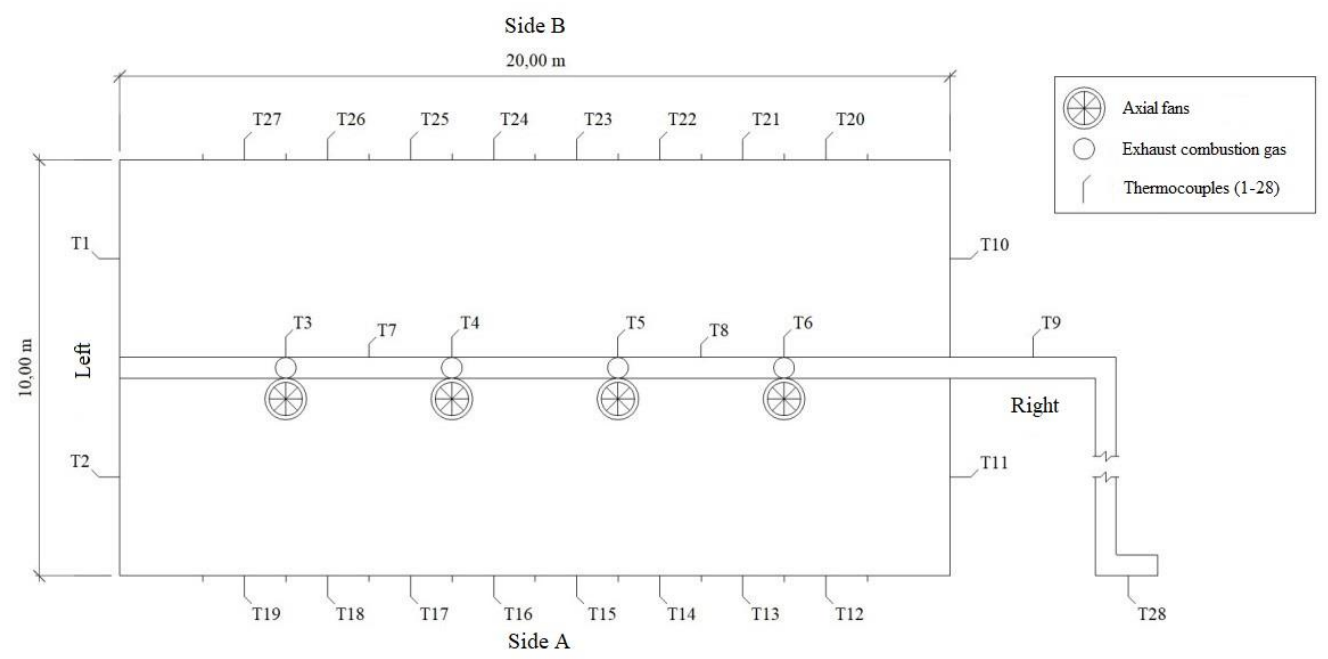

Figure 1. Wood dryer floor plan.

Figura 1. Planta baixa do secador de madeira. 


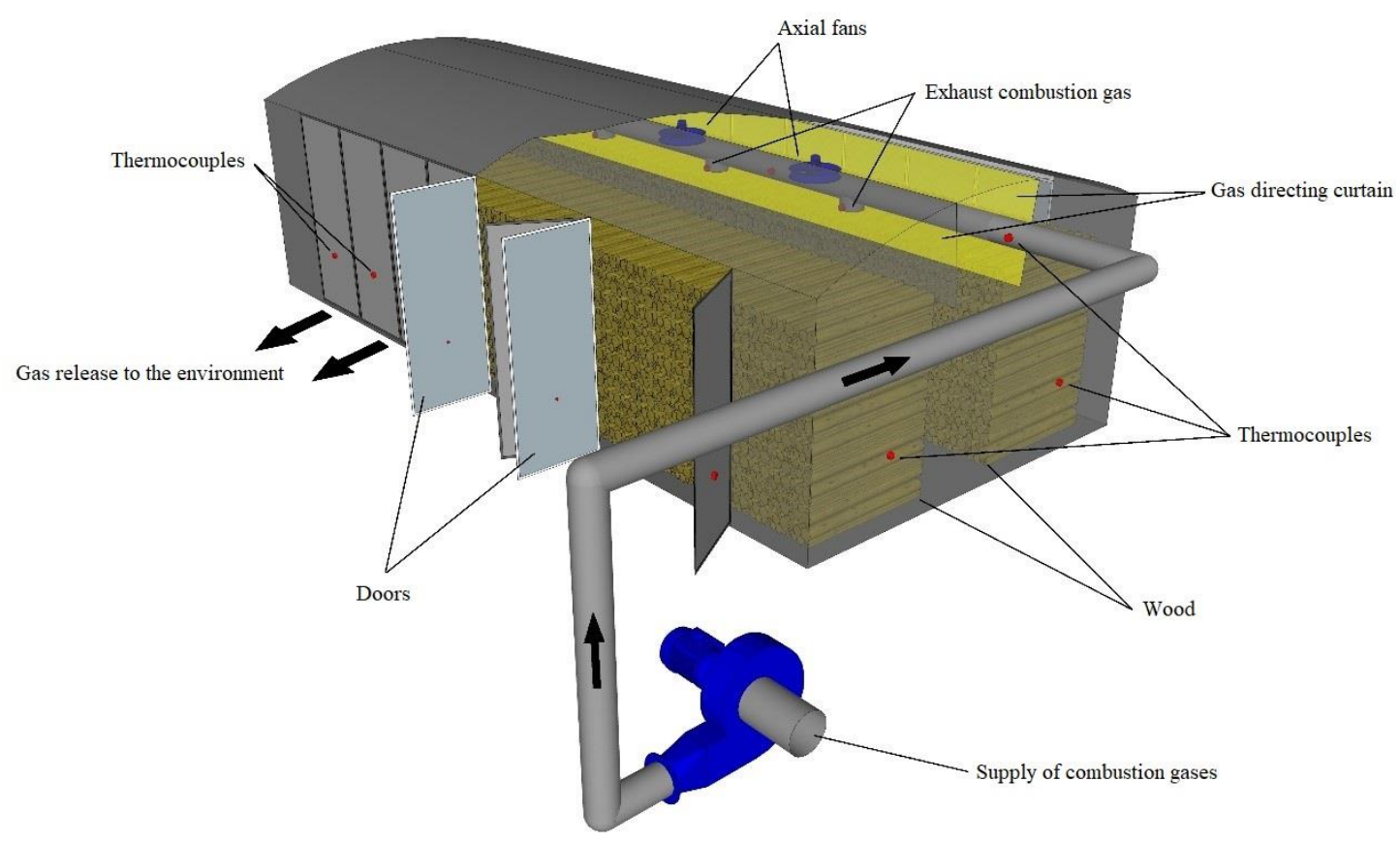

Figure 2. Schematic diagram of the wood dryer.

Figura 2. Diagrama esquemático do secador de madeira.

The combustion gases were conducted to the dryer through a metal duct with $0.30 \mathrm{~m}$ of internal diameter and $33 \mathrm{~m}$ of length, using a $25 \mathrm{hp}$ exhaust fan. The ducts were constructed using $1.25 \mathrm{~mm}$ thick galvanized steel sheets without thermal insulation.

Two piles of wood were arranged inside the dryer approximately 4.0 meters high and 3.0 meters wide (corresponding to the length of the logs), 2 meters apart from each other. The woods used were divided into two classes of diameter: Class I ( $12.5 \mathrm{~cm}$ mean diameter) and Class II ( $16.5 \mathrm{~cm}$ mean diameter).

The drying of the wood was performed for 72 hours, with average admission temperature of the gases in the dryer between 100 and $150{ }^{\circ} \mathrm{C}$. To obtain the moisture content of the logs, each wood pile was divided in four strata and three heights, generating 12 sub-strata. For each sub-strata two control samples (wood logs) were allocated of Class I and Class II, totaling 48 sample units per wood pile.

To determine the moisture content in dry basis, ABNT NBR 14929 (ABNT, 2003) was used. The wood control samples were weighed individually before and after drying. At the end of the process, three discs were taken from each sample $(\log )$ along its length, one disc in the center and the other two equidistant $50 \%$ from the center and the borders. To determine the initial moisture content of the control samples the logs were weighed before the test, and after drying to determine the final moisture content. Based on the final moisture content and initial mass, the initial moisture content was determined. The dry mass of the samples was calculated by equation (1) and the initial moisture content by equation (2).

$$
\mathrm{Md}=\frac{\mathrm{Ma}}{1+\left(\frac{\mathrm{Mf}}{100}\right)}
$$

where: $\mathrm{Md}=$ estimated dry mass of control sample $(\mathrm{kg}) ; \mathrm{Ma}=$ mass of control sample after drying $(\mathrm{kg}) ; \mathrm{Mf}=$ Average final moisture content of the disks (\%).

$$
\mathrm{Mi}=\left(\frac{\mathrm{Mb}-\mathrm{Md}}{\mathrm{Md}}\right) * 100
$$

where: $\mathrm{Mi}=$ estimated initial moisture content $(\%) ; \mathrm{Mb}=$ mass of control sample before drying $(\mathrm{kg}) ; \mathrm{Md}=$ estimated dry mass of control sample $(\mathrm{kg})$. 
The increase in gravimetric yield was estimated based on the gain of dry mass in charcoal provided by the reduction of moisture content of the wood in the kiln (Equation 1). Subsequently, the estimated gravimetric yield in charcoal obtained by drying the wood (Equation 2) was determined.

$$
\text { Dry mass gain of charcoal }(\mathrm{Kg})=\left[\frac{\frac{\mathrm{WR} * 600}{\mathrm{NCV}}}{1+\frac{\mathrm{M}}{100}}\right] * \mathrm{CY}
$$

where: $\mathrm{WR}=$ water mass removed from wood during drying; $\mathrm{NCV}=$ net calorific value of wood; $\mathrm{M}=$ wood moisture (dry basis); CY = usual charcoal yield of the company.

$$
\text { Estimated yield with drying }(\%)=\frac{M G C+C M}{D M W}
$$

where: $\mathrm{MGC}=$ mass gain of charcoal; $\mathrm{CM}=$ charcoal mass usually produced by the company without drying; DMW $=$ dry mass of wood in the kiln.

Thus, the increment in gravity yield of charcoal, obtained by incorporating the drying operation, was calculated by subtracting the estimated gravimetric yield in charcoal with wood drying by the gravimetric yield without wood drying.

The values of net calorific value, mass of charcoal produced without wood drying, dry mass of wood in the kiln and gravimetric yield without wood drying used for the calculations were provided by the forestry company where the study was conducted. These values are presented in Table 1.

Table 1. Data for determining the increase in gravimetric yield obtained with drying

Tabela 1. Dados para determinação do incremento em rendimento gravimétrico obtidos com a secagem

\begin{tabular}{lc}
\hline Parameters & Values \\
\hline Net calorific value (Kcal/Kg) & $1.068,91$ \\
Mass of charcoal produced without wood drying (ton) & $47.000,00$ \\
Dry mass of wood in the kiln (ton) & $14.242,24$ \\
Gravimetric yield without wood drying (\%) & 33,00 \\
\hline
\end{tabular}

\section{Statistical analysis}

Wood moisture loss data were subjected to Lilliefors test for normality and Cochran test to homogeneity of variances. Then, the results were submitted to analysis of variance (ANOVA) to verify the differences between diameter classes and the position in the dryer. When significant differences were established between them, the Tukey test with $95 \%$ significance level was applied.

\section{Evaluation of the economic viability of the project}

To assess the economic viability of the artificial wood dryer, the Discounted Cash Flow (DCF) method was used, which estimates the discounted project value at a rate that reflects the risk associated with the investment. In this methodology, the project value is measured by the amount of financial resources that will be generated in the future by the business, which is brought to present value to reflect the time and risk associated with the distribution (MARTELANC et al., 2010).

The financial indicators used to analyze the economic viability were the Net Present Value (NPV), the Internal Rate of Return (IRR) and the discounted Payback indicator. The NPV (5) is the formula used to determine the present value of discounted future payments at a given interest rate, minus the cost of the initial investment. A project will be economically viable if its NPV is positive at a certain discount rate. The higher the NPV, the more economically attractive the project will be (RODRIGUES \& ROZENFELD, 2015).

$$
\mathrm{NPV}=\sum_{\mathrm{j}=0}^{\mathrm{n}} \operatorname{Rj}(1+\mathrm{i})^{-\mathrm{j}}-\sum_{\mathrm{j}=0}^{\mathrm{n}} \mathrm{Cj}(1+\mathrm{i})^{-\mathrm{j}}=\sum_{\mathrm{j}=1}^{\mathrm{n}} \frac{\mathrm{CF}_{j}}{(1+i)^{j}}-C F_{0}
$$

where: $\mathrm{i}=$ discount rate; $\mathrm{Cj}=$ cost at the end of year $\mathrm{j} ; \mathrm{Rj}=$ revenue at the end of year $\mathrm{j} ; \mathrm{n}=$ project duration in years; $\mathrm{CF} 0=\mathrm{Cash}$ flow verified at time zero; $\mathrm{CFj}=$ Projected cash flows for each time interval. 
The IRR (6) is the discount rate that equals the present value of revenues to the present value of costs, that is, equals NPV to zero (MARTELANC et al., 2010).

$$
\sum_{j=0}^{n} R j(1+T I R)^{-j}=\sum_{j=0}^{n} C j(1+T I R)^{-j}
$$

where: $\mathrm{Cj}=$ cost at the end of year $\mathrm{j} ; \mathrm{Rj}=$ revenue at the end of year $\mathrm{j} ; \mathrm{n}=$ project duration in years.

Discounted Payback (7) is used to determine how long an investment takes to be repaid. Its calculation considers discounted flows, brought to present value, to determine when cash flows pay the initial investment (RODRIGUES \& ROZENFELD, 2015).

$$
\text { Discounted Payback }=\frac{\left|D A C F_{j-}\right|}{\left(\left|D A C F_{j-}\right|+\left|D A C F_{j+}\right|\right)} \times\left(A n o_{+}-A n o_{-}\right)+A n o_{-}
$$

where: $\mathrm{DACF}$ = discounted accumulated cash flow in year $\mathrm{j}$; positive series $(+)$; negative series (-).

To assemble the cash flow, the cost and revenue information was obtained from the forestry company where the study was performed, as in Table 2.

Table 2. Data for economic valuation of the charcoal production

Tabela 2. Dados para modelagem econômica da produção de carvão vegetal

\begin{tabular}{lcc}
\hline Item & Unit & Value \\
\hline Fixed costs per production & & $5.600,00$ \\
\hline Wood acquisition cost & $\mathrm{R} \$$ & $2.309,8$ \\
Carbonization cost & $\mathrm{R} \$$ & $300.000,00$ \\
\hline Costs of the dryer project per production & $\mathrm{R} \$$ & 10 \\
\hline Total investment in the dryer & Years & 10,00 \\
Dryer lifespan & $\%$ per year & 12,50 \\
Depreciation rate & $\mathrm{R} \$ / \mathrm{hour}$ & 72 \\
Labor cost & Hours & 0,75 \\
Worked hours & $\mathrm{R} \$ / \mathrm{kWh}$ & $1.640,5$ \\
Electricity cost & $\mathrm{kWh}$ & 120,44 \\
Exhaust fan and dryer motor consumption & $\mathrm{R} \$ / \mathrm{hour}$ & 7,0 \\
Machine Cost & Hours & 700,00 \\
Machine time (loading and unloading) & $\mathrm{R} \$ /$ ton & \\
Sales price of charcoal & & \\
\hline
\end{tabular}

The other information required for the feasibility analysis were: the expected useful life of the dryer in the financial modeling was 10 years, with a total investment required of $\mathrm{R} \$ 300$ thousand (year zero), 100\% financed by BNDES at a real interest rate of $4.00 \%$ per year (BNDES Finame - BK Produção), with a deadline of 24 months, a grace period of 12 months, with monthly payments through SLA - Straight Line Amortization. The depreciation rate was determined at $10 \%$ per year, and the annual income tax at $34 \%$. The minimum acceptable rate of return (MARR) was set at $8 \%$ per year, which is common for energy projects (MARTELANC et al., 2010).

Fifteen complete batches (productions) were estimated per year, each with a total duration, that is, average drying time plus carbonization of 23.3 days ( 20 carbonization days plus 3.3 drying days, including loading and unloading). Since the projected cash flow is monthly, 1.29 productions per month (15 batches divided over 12 months) were estimated. The total cost and total revenue values were multiplied by the factor 1.29.

FLORESTA, Curitiba, PR, v. 50, n. 1, p. 943 - 952, jan/mar 2020 


\section{RESULTS AND DISCUSSION}

\section{Wood drying}

Figure 3 shows the temperatures of the combustion gas transport system from the exhaust fan to its outlet inside the dryer, as a function of the drying time. Temperature fluctuations occur over time. These variations are explained by the insufficient supply of combustion gases to maintain the dryer temperature throughout the process.

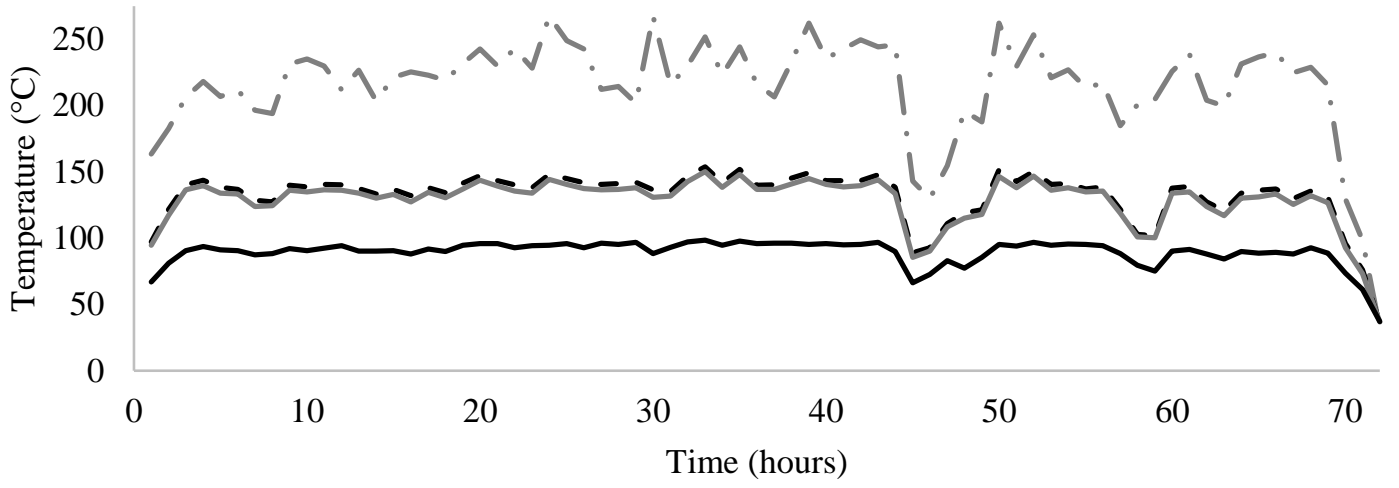
- - Exhaust fan
- - - Intake of gas transport piping to dryer
First gas outlet inside the dryer
Second gas outlet inside the dryer

Figure 3. Combustion gas temperature, depending on the drying time, along the transport pipes.

Figura 3. Temperatura dos gases combustos, em função do tempo de secagem, ao longo das tubulações de transport.

The average temperature difference between the gas transported from the exhaust fan and the gas in the dryer inlet was $80^{\circ} \mathrm{C}$. The temperature reduction of the first to the second interior gas outlet of the dryer was 39.6 ${ }^{\circ} \mathrm{C}$. In general, the thermal losses that occur in the combustion gases transport system inside the dryer can be attributed to the lack of a thermal insulation structure of this pipe and the distance traveled by the combustion gases along the pipes (BRAULIO et al., 2006 ).

The average gas temperature in the dryer ceiling was $44.52{ }^{\circ} \mathrm{C}$, which is lower than the average gas temperature in the dryer inlet (Figure 4 ), which was $138.74{ }^{\circ} \mathrm{C}$. Side B had the lowest temperatures compared to Side A. This fact is explained by the absence of axial fans in the Side B of the dryer, which impaired its heating. However, there were no differences in moisture loss between wood piles. The internal temperature of the dryer at the end of drying process was higher than the initial one, indicating the heating of the system, including wall, floor, ducts and mainly wood.

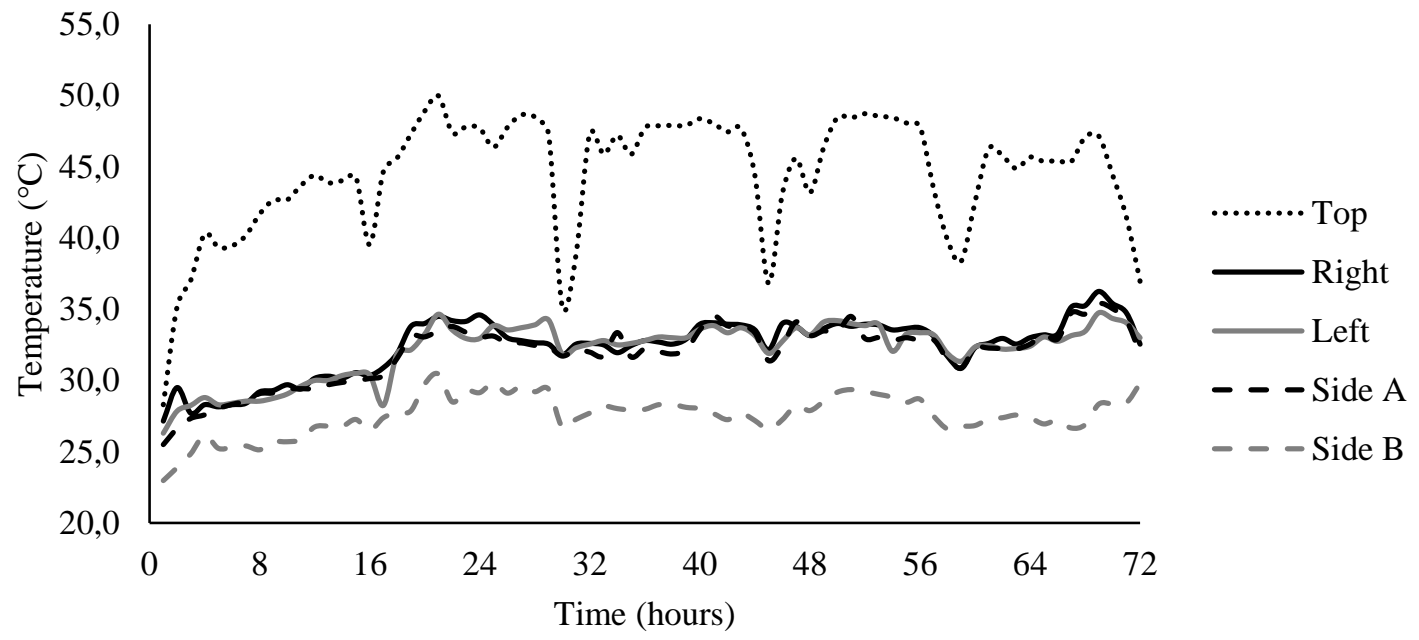

Figure 4. Thermal profile of the metallic dryer drying the time.

Figura 4. Perfil térmico do secador ao longo do tempo de secagem. 
Although the walls of the dryer consist of parallel metal sheets and internally insulated by ceramic blanket, in the regions of the junctions between the doors there was no thermal insulation, thus contributing to the heat exchange of the interior of the dryer with the environment.

Figure 5 shows that the moisture loss as a function of diameter class did not present significant differences. The effect of diameter on wood drying in eucalyptus logs was verified by Zanuncio et al. (2014) and Oliveira et al. (2017). These authors observed that smaller diameters had higher drying rates, compared to the ones with larger diameter logs. The present study did not present results that corroborate these works. That the variation between the two diameter classes used, Class I (mean diameter $12.5 \mathrm{~cm}$ ) and Class II (mean diameter $16.5 \mathrm{~cm}$ ), was probably not sufficient to result in significant differences in moisture loss. This fact is attributed to the constant improvement of the homogeneity of planted forests, which through efficient breeding programs and silvicultural techniques, allow the minimization of diametric variations between trees and along the same tree in a crop.

10
08
$\overbrace{04}^{06}$
02
00

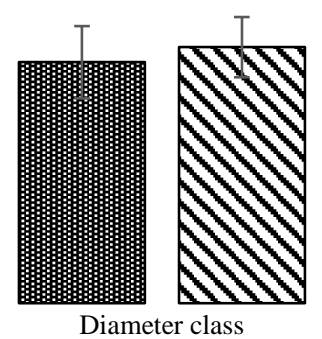

田 $\mathbf{I I I}$

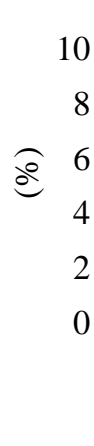

a

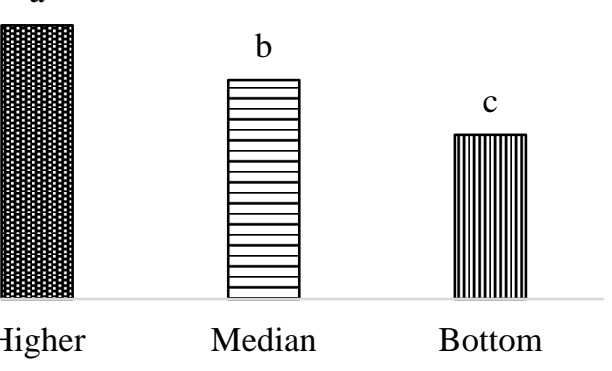

Position in the pile

Means followed by the same letter do not differ from each other at 5\% probability by the Tukey test

Figure 5. Loss of moisture depending on the diameter class (I) and as a function of position in the wood pile (II). Figura 5. Perda de umidade em função da classe de diâmetro (I) e em função da altura na pilha de madeira (II).

In the upper part there was a greater reduction of wood moisture in relation to the lower and median part (Figure 5). The first contact between the combustion gases and the wood occurs in the upper portion of the pile, where the passage of the hot gas (forced by the axial fans) in the wood of this region, causes energy losses (heat), thus reducing the capacity of gas drying in the lower positions.

With the use of a drying system there was an increase of $3.3 \%$ in the gravimetric yield in charcoal. Although apparently a small value, this increase in charcoal productivity, when occurring on an industrial scale, where thousands of tons of charcoal can be produced annually, represents a significant improvement in the production process of this material.

High moisture content can increase wood consumption to generate thermal energy, used in carbonization kilns to remove water from the system. When wood goes to carbonization with lower moisture content, this system energy consumption decreases. During the first stage of carbonization, characterized by wood drying, a high moisture content can lead to a higher formation of particulate matter (soot) and toxic bio-products (YANG et al., 2007). In addition, it can increase the production of gases (water vapor), thus causing a parenchyma cell disruption, and consequently greater charcoal friability (ZANUNCIO et al., 2014).

\section{Economic viability}

Table 3 shows that only in year 2 the cash flow is negative, where there is a negative debt accounting of $\mathrm{R} \$ 300$ thousand. In addition, the project achieved positive net income every year. For the discounted Payback indicator, as shown in the accumulated cash flow, the project takes six years to be repaid.

Table 3. Estimated cash flow of the carbonization + dryer project (in Reais BRT)

Tabela 3. Fluxo de caixa estimado para o projeto de carbonização + secador (em Reais BRT) 


\begin{tabular}{|c|c|c|c|c|c|c|c|c|c|c|c|}
\hline Year/Item & 0 & 1 & 2 & 3 & 4 & 5 & 6 & 7 & 8 & 9 & 10 \\
\hline Production (kg) & - & 331.850 & 331.850 & 331.850 & 331.850 & 331.850 & 331.850 & 331.850 & 331.850 & 331.850 & 331.850 \\
\hline Production revenue & - & 232.295 & 232.295 & 232.295 & 232.295 & 232.295 & 232.295 & 232.295 & 232.295 & 232.295 & 232.295 \\
\hline Carbonization cost & - & $(122.256)$ & (122.256) & $(122.256)$ & (122.256) & $(122.256)$ & $(122.256)$ & (122.256) & $(122.256)$ & (122.256) & $(122.256)$ \\
\hline Drying cost & - & $(45.958)$ & $(45.958)$ & $(45.958)$ & $(45.958)$ & $(45.958)$ & $(45.958)$ & $(45.958)$ & $(45.958)$ & $(45.958)$ & (45.958) \\
\hline Financial expenses & - & $(11.785)$ & (11.785) & - & - & - & - & - & - & - & - \\
\hline Depreciation & - & $(30.000)$ & (30.000) & $(30.000)$ & $(30.000)$ & $(30.000)$ & $(30.000)$ & $(30.000)$ & $(30.000)$ & $(30.000)$ & $(30.000)$ \\
\hline PBIT & - & 22.296 & 22.296 & 34.081 & 34.081 & 34.081 & 34.081 & 34.081 & 34.081 & 34.081 & 34.081 \\
\hline IT & - & $(7.581)$ & $(7.581)$ & (11.588) & (11.588) & (11.588) & (11.588) & (11.588) & $(11.588)$ & $(11.588)$ & (11.588) \\
\hline Net profit & - & 14.715 & 14.715 & 22.494 & 22.494 & 22.494 & 22.494 & 22.494 & 22.494 & 22.494 & 22.494 \\
\hline Depreciation & - & 30.000 & 30.000 & 30.000 & 30.000 & 30.000 & 30.000 & 30.000 & 30.000 & 30.000 & 30.000 \\
\hline Investments & $(300.000)$ & - & - & - & - & - & - & - & - & - & - \\
\hline Gross debt & 300.000 & - & - & - & - & - & - & - & - & - & - \\
\hline Amortization & - & - & $(300.000)$ & - & - & - & - & - & - & - & - \\
\hline Cash flow & - & 44.715 & (255.285) & 52.494 & 52.494 & 52.494 & 52.494 & 52.494 & 52.494 & 52.494 & 52.494 \\
\hline $\mathrm{DCF}$ & - & 41.403 & (218.866) & 41.671 & 38.584 & 35.726 & 33.080 & 30.629 & 28.361 & 26.260 & 24.315 \\
\hline$A D C F$ & - & 41.403 & $(177.463)$ & (135.792) & (97.207) & $(61.481)$ & $(28.401)$ & 2.228 & 30.589 & 56.849 & 81.163 \\
\hline
\end{tabular}

Legend: PBIT = Profit before income tax; IT = Income Tax. Net profit = PBIT - IT. DCF = Discounted Cash Flow. ADCF = Accumulated Discounted Cash Flow; Parentheses indicate negative values

By conducting the economic analysis through Discounted Cash Flow, the project proved economically viable, even taking into account the investments required to implement the dryer (financing, financial expenses, depreciation) in addition to the new operating costs of the drying process. In the base case, with a discount rate of $8 \%$ per year, the NPV was R\$ 75.15 thousand and the project IRR was $19.96 \%$. That is, the project obtained positive NPV and IRR above the minimum acceptable rate of return (MARR). With the project's discount rate increasing from $8 \%$ to $10 \%$ and $12 \%$, the NPV still remains positive at R \$ 55.56 thousand and R \$ 39.55 thousand, respectively, which shows are good economic indicators even under higher discount rates.
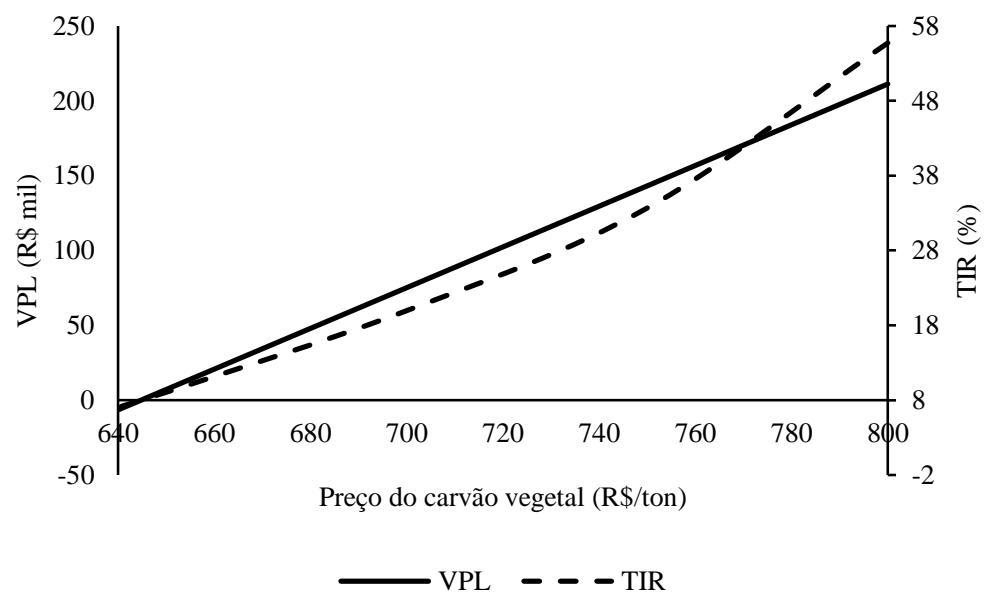

Legend: VPL $=$ Net Present Value; TIR = Internal Rate of Return

Figure 6. Financial indicators sensibility in relation to the charcoal price.

Figura 6. Sensibilidade dos indicadores financeiros com relação ao preço do carvão vegetal. 
As noted in Figure 6, if the selling price of charcoal is greater, the NPV and IRR are also better, which was expected, since the project revenue is solely dependent on price and production. On the other hand, if the selling price of charcoal is lower, at R \$ 640.00/ton for example, the NPV will be negative at R $\$ 6.50$ thousand and the IRR will be $7.04 \%$, below the MARR of $8 \%$, making the project economically unviable. Therefore, the selling price of charcoal is a very significant variable for the viability of the project.

\section{CONCLUSIONS}

- The use of the metal dryer is technically viable, reducing the wood moisture content by $8 \%$ on average and providing a $3.3 \%$ increase in charcoal productivity.

- The project has economic viability, with discounted payback of 6 years, however it is sensitive to variations in the sale price of charcoal, which should be above R $\$ 640$ per ton.

- Increasing drying efficiency requires improvements in thermal insulation and insertion of drawing points of wet gases.

\section{ACKNOWLEDGEMENTS}

To the G6 Charcoal Thematic Group, the Foundation for Research of the State of Minas Gerais (FAPEMIG), National Council for Scientific and Technological Development (CNPq), the Brazilian Agricultural Research Corporation (Embrapa Forestas), the technical support from the Laboratory of Wood Panels and Energy (LAPEM / DEF / UFV), in particular Salvio Teixeira and Davi Oliveira.

\section{REFERENCES}

ABNT - ASSOCIAÇÃO BRASILEIRA DE NORMAS TÉCNICAS. NBR 14929: Madeira: determinação da densidade básica. Rio de Janeiro, 2003. 6 p.

BRAUliO, M. A. L.; BONADIA, P.; GALlO, J. B.; PANDOLFELli, V. C. Análise sistêmica para seleção de refratários para transporte de alumínio líquido. Cerâmica, São Paulo, v.52, n.323, p. 115-122, 2006.

GOMIDE, L. R; SCOLFOR, J. R. S; OLIVEIRA, A. D. Análise das estruturas diamétricas e hipsométricas de fragmentos florestais localizados na bacia do rio São Francisco, em Minas Gerais. Floresta, Curitiba, v. 39, n. 2, 2009.

INTERNATIONAL ENERGY AGENCY (IEA). Global renewable energy policies \& Measures Database. Disponível em: <www.iea.org/policiesandmeasures/renewableenergy/>, 2017.

KORHONEN, J.; HONKASALO, A.; SEPPALA, J. Circular Economy: The Concept and its Limitations. Ecological Economics, v.143, p.37-46, 2018.

MARTElanc, R.; PASIN, R.; CAVAlCANTE, F. Avaliação de Empresas: Um Guia para Fusões \& Auisições e Gestão de Valor. Pearson/Financial Times, 2010.

OLIVEIRA, A.C.; PEREIRA, B.L.C.; CARNEIRO, A.C.O.; FIALHO, L.F.; FIGUEIRÓ, C.G.; VITAL, B.R.; MAGALHÃES, M.A. Eucalyptus logs drying at high temperatures. Revista Árvore, v. 41, n. 2, 2017.

PENNISE, D. M.; SMITH, K. R.; KITHINJI, J. P.; REZENDE, M. E.; RAAD, T. J.; ZHANG, J.; FAN, C. Emissions of greenhouse gases and other airborne pollutants from charcoal making in Kenya and Brazil. Journal of Geophysical Research Atmospheres, v. 106, p. 24143 - 24156, 2001.

PEREIRA, B.L.C.; OLIVEIRA, A.O.; CARVALHO, A.M.M.L.; CARNEIRO, A. de C.O.; SANTOS, L.C.; VITAL, B.R. Quality of wood and charcoal from Eucalyptus clones for ironmaster use. International Journal of Forestry Research, v.2012, p.1-8, 2012.

PEREIRA, E. G.; MARTINS, M. A.; PECENKA, R.; CARNEIRO, A. C. O. Pyrolysis gases burners: Sustainability for integrated production of charcoal, heat and electricity. Renewable and Sustainable Energy Reviews, v.75, p.592-600, 2017. 
RODRIGUES, K.F.C; ROZENFELD, H. Análise de Viabilidade Econômica. EI2, Grupo Engenharia Integrada e Engenharia de Integração. Divulgado em março, 2015. Portal de Conhecimentos:

<http://www.portaldeconhecimentos.org.br/index.php/por/content/view/full/16949>. Acesso em: 20 de abril 2018.

VERMA, M.; LOHA, C.; SINHA, A. N.; CHATTERJEE, P. K. Drying of biomass for utilising in co-firing with coal and its impact on environment - A review. Renewable and Sustainable Energy Reviews, v.71, p.732-741, 2017.

WELFLE, A. Balancing growing global bioenergy resource demands - Brazil's biomass potential and the availability of resource for trade. Biomass and Bioenergy, v.105, p.83-95, 2017.

YANG, H.; YAN, R.; CHEN, H.; LEE, D.H.; ZHENG, C. Characteristics of hemicellulose, cellulose and lignin pyrolysis. Fuel, v. 86, 2007.

ZANUNCIO, A. J. V.; LIMA, J. T.; MONTEIRO, T. C.; TRUGILHO, P. F.; LIMA, F. S. Secagem ao Ar Livre da Madeira para Produção de Carvão Vegetal. Floresta e ambiente, Seropédica, v. 21, n. 3, 2014. 